\title{
THE ROLES OF THE NARRATOR IN RADIO FEATURES
}

\author{
Susana Herrera Damas ${ }^{1}$
}

\begin{abstract}
Although for time and economic reasons radio feature is not as common as other genres, it is a very necessary and useful type of text today. Thanks to it journalists can provide more perspective and better contextualize the facts. To do so, a narrator is required. The aim of this paper is to describe the different roles that narrators can play in radio features. As we will see, this figure must play some mandatory functions, whereas others are optional. Among the mandatory, we fill find the perceptual and narrative functions. The communicative, testimonial and administrative functions are optional. The prevalence of one function or another leads us to several types of narrator.
\end{abstract}

Because of time, technology and economic factors, radio feature is not a very common genre today, though it is still a very useful and necessary type of text. With radio features, journalists can provide more perspective on the facts and better contextualize them. But to do this, a narrator is required. The aim of this paper is to describe the

1 Susana Herrera Damas is a professor at Universidad Carlos III de Madrid

Recherches en communication, $\mathrm{n}^{\circ} 37$ (2012). 
different roles that narrators can play in radio features. As we will see, the narrator must adhere to some mandatory functions, though others are optional. The mandatory ones include the perceptual and narrative functions, while the communicative, testimonial and administrative functions are optional. The prevalence of one function over another leads us to several different types of narrator.

From a methodological point of view, we will take into account the theory of literature, a review of journalistic genres and an analysis of some of the best radio features broadcasted by Cadena SER over recent years.

The feature is a model of representation of reality based on monologue and aimed at describing interesting facts and actions, providing a comprehensive context of interpretation (a rich and varied production) and a careful and creative aesthetic construction (Martínez-Costa \& Díez Unzueta, 2005, p. 114).

\section{Mandatory roles}

As the following literature suggests (Genette, 1989, pp. 308-312, García Landa, 1998, pp. 298-299 \& Garrido Domínguez, 1996, pp. 119-121), radio feature narrators must also carry out two compulsory roles: the perceptive and the narrative ones.

\section{The perceptive role}

The perceptive role refers to the way in which the narrator has had access to the information. This is an indispensable role because any narrator must see something before telling the audience about it. This function is closely tied to the concept of focalization, which is also known as perspective or point of view. Literature identifies three types of focalization (Genette, 1989, pp. $244 \&$ following):

\section{Internal focalization}

This assumes that the narrator and the character are the same because the narrator is located inside a character and sees everything from his perspective. This type of focus can be: 
a) Unique: If the narrator focuses on a single character, which becomes the central subject of the story. This happens in those features where the narrator is auto-diegetic and stars in the story. This example can be seen, for instance, in the feature "Impossible Challenge" by Severino Donate, where a reporter ironically narrates the troubles faced by a 29 year old young man trying to buy an apartment in the city of Madrid.

b) Multiple or variable: this combines different perspectives. It reveals a very active narrator who is, however, limited by the restrictions of each focus. This narrator seamlessly "jumps" from the consciousness of one character to another. We can see this in "Zorita Closes", which tells the story of a nuclear power station located in Almonacid. In this example, the reporter visits the town once its closing-down was announced. The feature includes the views of several villagers.

\section{External focalization}

The narrator knows less than the characters. He only knows what can be seen from the outside and via his senses. He tries to show or explain the behavior of the characters, but without taking into account their thoughts or feelings because he lacks access to them.

\section{Zero focalization or omniscience}

This narrator has no limits: he knows much more than any of the characters. What is more, he knows everything. Unlike those narrators discussed above, this narrator details reality from a multiple rather than a singular perspective. He is able to see everything, although naturally, within this ability, we can find several degrees.

a) In the editorial omniscience, the narrator is a kind of judge who dares to criticize and evaluate everything about the characters: their present, past, future, thoughts, feelings, etc. However, this style of narration is more limited in radio features because the informative attitude is at the very heart of the genre.

b) In the neutral omniscience, the narrator knows everything and has lots of information about the inner world of the characters. However, he does not make judgments or even express whether he is 
for or against something. It is obvious that this narrator will always face the limitation of his own subjectivity, but, at least, he tries not to explicitly judge the facts.

c) In the limited or selective omniscience, the omniscient narrator rests upon a single figure. Unlike the two previous omnisciences, this kind of narrator knows "everything" about just one character in particular, rather than about all the characters. In contrast with an internal focus - where the narrator is "with" the character - in the selective omniscience the narrator is "inside" the character.

\section{The narrative role}

The narrative role corresponds to the transmission of the action. This is another required function and no narrator can deviate from it. To fulfill this function, the narrator must tell the audience what he has seen. There are several ways to do this according to the following two criteria: i) the level of story and ii) the author's participation in the action. Their combination results in six sorts of narrators (Pérez \& Herrera, 2007):

\section{Extra-heterodiegetic narrator}

This is a main narrator who tells a story in which he does not take part. In this case, the narrator has no direct involvement in the action, so he is able to maintain a greater objective or critical distance. We can find an example in the feature "Occupational Diseases", by Toñi Fernández. In it, the reporter reviews the symptoms of some diseases that are derived from the working conditions of certain jobs. The presence of an extra heterodiegetic narrator is enriched by the testimony of affected people suffering from several diseases. The feature is further enlightened by the testimony of doctors and psychologists.

\section{Extra-homodiegetic narrator}

This is a main narrator who tells a story that he has witnessed. We can find an example in "11-M Silences". Here, the reporter makes us witnesses of the void left by 7 of the 191 people who died on 11 March, 2004 in the terrorist bombings at the Atocha train station in Madrid. 


\section{Extra-autodiegetic narrator}

This is a main narrator who tells his own story, a story in which he is the protagonist. For this reason, the story is usually presented in first person. This is the case of "Impossible Challenge", by Severino Donate. The extra autodiegetic story is evident from the very opening of the feature.

\section{Intra-heterodiegetic narrator}

This narrator is located in a second level of the story. Therefore, he or she is inserted somehow into the general account. The main narrator provisionally delegates to this narrator to provide the story with more credibility and a greater aesthetic appeal.

In this case, the intra-heterodiegetic narrator usually corresponds to the voice of an expert. This narrator has not directly witnessed the action, but he has qualified authority due to his knowledge on the subject.

\section{Intra-homodiegetic narrator}

The intra homodiegetic narrator is also a secondary narrator, but unlike the former, he has witnessed the action, regardless of the fact that he is not its protagonist. In other words, he tells a story that he has witnessed.

\section{Intra-autodiegetic narrator}

This secondary narrator tells his own story, a story which he stars in. This strategy provides credibility and more rhythm to the story. This occurs in "Occupational Diseases", where several affected people describe their situation. Each of these victims are therefore intra-autodiegetic narrators. 


\section{Optional roles}

Besides the perceptive and narrative roles, radio feature narrators can also play some optional ones (Genette, 1989, pp. 308-312, García Landa, 1998, pp. 298-299 \& Garrido Domínguez, 1996, pp. 119-121): the communicative, the testimonial and the administrative roles.

\section{The communicative role}

Also called contact or phatic function, the communicative role involves a listener. This function can have a phatic nature when seeking to highlight the relationship towards the listener. It can be conative when the narrator aims to modify the listener's behavior. An example can be found in the feature "Mortgages" when the reporter says:

NARRATOR: Going to the streets to talk about mortgages and interest rates is so depressing, so I guess you do not mind if I sweeten it with some music ("Mortgages", Severino Donate).

\section{The testimonial role}

In this case, the narrator certifies his presence where the action takes place. This very important function shows that he has visited the place, something that has promotional and credibility-related implications.

\section{The administrative role}

Finally, through the administrative role the narrator draws attention to the way he delivers information. This function is more important in radio than in literature, precisely because of the ephemeral nature of the radio message. Thus, it is important for the narrator to make all possible efforts in his attempt to guide the listener's attention.

We find an example of this administrative function in the feature "High Accident Rates" where the reporter provides information on how she obtains the information:

NARRATOR: Two days later, we return with the inspector. It is warmer so we say goodbye to the suit jacket. We are in the in- 
dustrial area of the Alamo, about 35 kilometers from Madrid. It is half past ten in the morning

INSPECTOR: Let's make a visit to a company in the wood sector to check the circumstances of an accident. It is a loss of two or three fingers of his right hand. The company is indeed not aware that we will visit them ("High accident rates").

\section{Conclusion}

So far, these are the main roles that can be performed by narrators. As we can see, some of them are mandatory and others optional. The perceptive and the narrative ones are compulsory because they are characteristic of narrators. The remaining roles are optional, but in some cases highly recommended. The testimonial function, for instance, takes on special significance when the narrator is auto or homodiegetic because in both cases it affects his presence on the scene.

Something similar happens with the administrative function: even though it is not mandatory, it can be very effective as a means to grab the listener's attention and to guide him through the text. Similarly, the communicative function allows the reporter to call the listener's attention to the information he wants to highlight. In this sense, both are guiding roles, because the administrative role guides the listener's attention over time, whereas the communicative one advises him about what the more or less important aspects are of the various choices presented to the character.

In conclusion, the only role that is more limited is the editorial or ideological one (Genette, 1989, p. 310) Through this role the narrator explicitly evaluates the action. This function can be assumed by witnesses, victims, those affected or experts on the subject. However, it should not be explicitly held by the main narrator. This is explained by the informative nature of the feature. 


\section{References}

Balsebre, A. (1994). El lenguaje radiofónico. Salamanca: Cátedra.

García Landa, M.A. (1998). Acción, relato, discurso (Estructura de la ficción narrativa), Salamanca: Universidad de Salamanca.

Garrido, A. (1996). El texto narrativo, Madrid: Síntesis.

Genette, G. (1989). Figuras III, Barcelona: Lumen.

Gutiérrez García, M., \& Perona, J.J. (2002). Teoría y técnica del lenguaje radiofónico, Barcelona: Bosch Comunicación.

Herrera, S. (2007a). El reportaje en radio: anatomía de un género. In Ámbitos, 16, pp. 91-105.

Herrera, S. (2007b). La estructura del reportaje en radio. In Área Abierta, 17, available at: http://www.ucm.es/info/cavp1/Area\%20Abierta/17\%20Area\%20Abierta/ articulos/Herrera88.pdf

Herrera, S. (2007c). Las cualidades del buen creador de reportajes de radio. In Representaciones, 2, pp. 81-101.

Herrera, S. (2007d). Los peligros de los que huir al elaborar reportajes en radio. In Revista Question, 15, available at: http://perio.unlp.edu.ar/question/nivel2/articulos/ informes_investigacion/herreradamas_1_informes_15invierno07.htm

Herrera, S. (2007e). El reportaje en radio: aspectos que configuran su estilo. In Consensus, 12(1), pp. 65-76.

Herrera, S. (2007f). Cómo elaborar reportajes en radio. In Temas y Problemas de la Comunicación, 14, pp. 79-97, available at: http://www.unrc.edu.ar/insti/05/comu/ temasyproblemas/n14.html

Herrera, S. (2008a). Tipología del reportaje radiofónico. In Tercer Milenio, 13(16), pp. 58-74.

Herrera, S. (2008b). Cómo elaborar reportajes en radio, Buenos Aires: La Crujía Ediciones.

Huertas, A., \& Perona, J.J. (1999). Redacción y locución en medios audiovisuales: la radio, Barcelona: Bosch Comunicación.

Martínez-Costa, M.P., \& Díez Unzueta, J.R. (2005). Lenguaje, géneros y programas de radio. Introducción a la narrativa radiofónica, Pamplona: Eunsa.

Pérez Esain, C., \& Herrera, S. (2007). Tipología del narrador en los reportajes radiofónicos. In Vozes e Diálogo, 9, pp. 57-68.

Prado, E. (1981). Estructura de la información radiofónica, Barcelona: ATE.

Rodero, E. (2001). Manual práctico para la realización de entrevistas y reportajes en la radio, Salamanca: Librería Cervantes.

Ulibarri, E. (1994). Idea y vida del reportaje, México: Trillas. 